\title{
Influence of Various Zinc and Iron Treatments on Nutrient Content and Uptake of Grain and Stover of Pear Millet Crop
}

\author{
C. D. Parmar ${ }^{1}$, R. R. Kharadi ${ }^{1}$ and K. P. Bhuriya ${ }^{2^{*}}$ \\ ${ }^{1}$ Department of soil science and agricultural chemistry, B. A. College of Agriculture, Anand \\ Agricultural University, Anand, Gujarat (India)-388 110, India \\ ${ }^{2}$ Junagadh Agricultural University, Kodinar, Gujarat, India \\ *Corresponding author
}

\section{A B S T R A C T}

\begin{tabular}{l} 
Key w or d s \\
Pearl millet, N, P, K \\
Content and \\
Uptake, Stover, \\
Zinc and Iron \\
\hline Article Info \\
\hline $\begin{array}{l}\text { Accepted: } \\
\text { 26 July 2020 } \\
\text { Available Online: } \\
\text { 10 August } 2020\end{array}$ \\
\hline
\end{tabular}

\section{Introduction}

Pearl millet (Pennisetum glaucum (L.) is one of the important food grain crop of India ranking fourth in average to rice, wheat and sorghum in that order. Its common name over a large part of India is bajra or bajri. Pearlmillet cultivation is mainly confined to the arid and semi - arid zones prehistoric time. Gujarat ranks third in the production of pearl millet in India whereas Rajasthan tops the list and Uttar Pradesh is in second position. It is cultivated over an area of 0.39 million hectares in Gujarat. The total production is
The present investigation was undertaken to study the "Influence of various zinc and iron treatments on nutrient content and uptake of grain and stover of pearmillet crop" was carried out during kharif season of the year 2016, at College Agronomy Farm, B. A. College of Agriculture, Anand Agricultural University, Anand. The soil of experimental plot was loamy sand in texture, low in organic carbon and available nitrogen, high in available phosphorus and potassium, DTPA extractable iron and zinc medium in available status. Pearlmillet variety GHB 558 was used as test crop. The non-significant effect of $\mathrm{Zn}$ and Fe containing fertilizer application was noticed on $\mathrm{N}, \mathrm{P}$ and $\mathrm{K}$ content in grain and stover of pearlmillet. Similarly, the N, P and K uptake by pearl millet were also not affected significantly due to different treatments.
0.79 million tones and the productivity is $2004 \mathrm{~kg} \mathrm{ha}^{-1}$ (Anon., 2016-17). The nutritive value of pearlmillet is fairly high. It contains 5 per cent fat (either extract), 9.15 per cent protein, 2.7 per cent mineral matter and gives 360 calorie per $100 \mathrm{~g}$ with high amount of vitamins $\mathrm{A}$ and $\mathrm{B}$, it imparts substantial energy to the body with easy digestibility. In addition on grain, it also supplies fair quality dry fodder in large bulk.

Agricultural produces, lower in micronutrient content, failed to meet up its ( $\mathrm{Zn})$ requirements for human nutrition (Singh 
\&Prasad, 2014). Continuous reliance on high proportion of cereals-based foods with low amount and availability of $\mathrm{Zn}$ appears to be the major reason for the widespread occurrence of the $\mathrm{Zn}$ deficiency problem in human.

Iron $(\mathrm{Fe})$ plays an important role in the plant growth. It is a cofactor for approximately 140 enzymes that catalyze unique biochemical reactions. Deficiency or low activity of iron in the plant causes chlorophyll is not produced in sufficient quantities and the leaves are pale. It helps in the formation of chlorophyll and is constituent of enzyme systems which bring about oxidation reductions in plants. $\mathrm{Fe}$ is essential for respiration, photosynthesis and fixation of atmospheric nitrogen by nitrogen fixing organisms.

Scenario of micronutrient deficiency in north India in early eighties was different than now after four decades. Zinc deficiency remained a major problem all over country. Zinc deficiency has increased from $44 \%$ to $48 \%$ and expected to further increase up to $63 \%$ by 2025 as most of the marginal soil are showing higher response to added zinc(Singh\& Ram 2006).

\section{Materials and Methods}

The filed study was planned to during kharif season of the year 2016 at the College Agronomy Farm, B. A. College of Agriculture, Anand Agricultural University, Anand. The experimental plot was prepared as per the method described by Bhuriya et al (2019). The soil of the experimental field was alkaline in reaction and soluble salt content under safe limit. It was low in organic carbon, available $\mathrm{N}$, low in available nitrogen, high in available phosphorus and available potash, while medium in available zinc and iron. Total 10 treatments were included in the present investigation treatments were comprised of $\mathrm{Zn}$ and $\mathrm{Fe}$ fertilizers application through $\mathrm{ZnSO}_{4}$ and $\mathrm{FeSO}_{4}$ as well as chelated forms of $\mathrm{Zn}$ and Fe. $\mathrm{T}_{1} 0 \mathrm{~kg} \mathrm{Zn} \mathrm{ha}{ }^{-1}+0 \mathrm{~kg} \mathrm{Fe}$ $\mathrm{ha}^{-1}$ (control), $\mathrm{T}_{2} 0 \mathrm{~kg} \mathrm{Zn} \mathrm{ha}{ }^{-1}+50 \mathrm{~kg} \mathrm{FeSO}_{4}$ $\mathrm{ha}^{-1}, \mathrm{~T}_{3} 0.5 \mathrm{~kg}$ Chelated $\mathrm{Zn} \mathrm{ha}{ }^{-1}+50 \mathrm{~kg} \mathrm{FeSO}_{4}$ $\mathrm{ha}^{-1}, \mathrm{~T}_{4} 1.0 \mathrm{~kg}$ Chelated $\mathrm{Zn} \mathrm{ha}^{-1}+50 \mathrm{~kg} \mathrm{FeSO}_{4}$ $\mathrm{ha}^{-1}, \mathrm{~T}_{5} 1.5 \mathrm{~kg}$ Chelated $\mathrm{Zn} \mathrm{ha}{ }^{-1}+50 \mathrm{~kg} \mathrm{FeSO}_{4}$ $\mathrm{ha}^{-1}, \mathrm{~T}_{6} 25 \mathrm{~kg} \mathrm{ZnSO}_{4} \mathrm{ha}^{-1}+0 \mathrm{~kg} \mathrm{Fe} \mathrm{ha}{ }^{-1}, \mathrm{~T}_{7} 25$ $\mathrm{kg} \mathrm{ZnSO}_{4} \mathrm{ha}^{-1}+0.5 \mathrm{~kg}$ Chelated Fe ha-1, T825 $\mathrm{kg} \mathrm{ZnSO} 4 \mathrm{ha}^{-1}+1.0 \mathrm{~kg}$ Chelated Fe ha ${ }^{-1}, \mathrm{~T}_{9} 25$ $\mathrm{kg} \mathrm{ZnSO}_{4} \mathrm{ha}^{-1}+1 . .5 \mathrm{~kg}$ Chelated Feha ${ }^{-1}, \mathrm{~T}_{10} 25$ $\mathrm{kg} \mathrm{ZnSO}_{4} \mathrm{ha}^{-1}+50 \mathrm{~kg} \mathrm{FeSO} \mathrm{ha}^{-1}$.

$\mathrm{Zn}_{0}, \mathrm{Zn}_{0.5}, \mathrm{Zn}_{1.0}$ and $\mathrm{Zn}_{1.5} 0.0,0.5,1.0$ and 1.5 kg Zn Chelated

$\mathrm{Fe}_{0}, \mathrm{Fe}_{0.5}, \mathrm{Fe}_{1.0}$ and $\mathrm{Fe}_{1.5}: 0.0,0.5,1.0$ and 1.5 kg Fe Chelated

$\mathrm{Zn}_{25}: \mathrm{ZnSO}_{4} 25 \mathrm{kgha}^{-1}$

$\mathrm{Fe}_{50}: \mathrm{FeSO}_{4} 50 \mathrm{kgha}^{-1}$

Analysis dried samples (leaf and grain) were digested in di-acid mixture $\left(4 \mathrm{HNO}_{3}: 1 \mathrm{HClO}_{4}\right)$ and volume was made up with double distilled water (Jackson, 1973). The extract was filtered through Whatman filter paper No. 42. The digested extract of plant samples was used for analysis of $\mathrm{P}, \mathrm{K}$ micronutrients and $\mathrm{N}$ content was analyzed by Kjeldahl digestion method.

\section{Results and Discussion}

\section{Effect of treatment on nutrient content and uptake by grain on pear millet}

Nitrogen, phosphorus and potash content of grain of pearl millet as influenced by application of zinc and iron are furnished in Table 1. It was observed from the data presented in Table that $\mathrm{N}, \mathrm{P}$ and $\mathrm{K}$ content did not significantly altered due to different treatments. In a trial with pearl millet, Yadav et al., (1989) reported that increasing $\mathrm{Zn}$ rates 
from 0,5 and $10 \mathrm{~kg} \mathrm{Znha}^{-1}$ did not affect on $\mathrm{N}$ content of grain of pearl millet.

The nutritive value of pearl millet crop is fairly high. It contains $12.4 \%$ moisture, 11.6 $\%$ protein, $5 \%$ fat, $67 \%$ carbohydrates and about $2.7 \%$ minerals.it is also rich in Vit-A, Vit-B and impart substantial energy for baby (360 calories $100 \mathrm{~g}^{-1}$ ) (Malik,2015). Pearl millet grains are eaten cooked like rice or "chapatis" are prepared out of flour like maize or sorghum flour.

Table.1 Effect of treatments on nutrient content and uptake by grain on pearmillet

\begin{tabular}{|c|c|c|c|c|c|c|c|}
\hline \multirow{2}{*}{\multicolumn{2}{|c|}{ Treatments }} & \multicolumn{3}{|c|}{ Nutrient content in grain (\%) } & \multicolumn{3}{|c|}{ Nutrient uptake in grain (\%) } \\
\hline & & $\mathbf{N}$ & $\mathbf{P}$ & $\mathbf{K}$ & $\mathbf{N}$ & $\mathbf{P}$ & $\mathbf{K}$ \\
\hline $\mathbf{T}_{1}$ & $\mathbf{Z n}_{0} \mathbf{F e}_{0}$ & 1.86 & 0.32 & 0.56 & 49.00 & 8.16 & 14.45 \\
\hline $\mathbf{T}_{2}$ & $\mathrm{Zn}_{0} \mathrm{Fe}_{50}$ & 1.81 & 0.32 & 0.55 & 50.42 & 9.04 & 15.21 \\
\hline $\mathbf{T}_{3}$ & $\mathrm{Zn}_{0.5} \mathrm{Fe}_{50}$ & 1.65 & 0.34 & 0.56 & 47.10 & 9.71 & 15.92 \\
\hline $\mathbf{T}_{4}$ & $\mathrm{Zn}_{1.0} \mathrm{Fe}_{50}$ & 1.86 & 0.33 & 0.53 & 54.93 & 9.61 & 15.75 \\
\hline $\mathbf{T}_{5}$ & $\mathbf{Z n}_{1.5} \mathbf{F e}_{50}$ & 1.84 & 0.32 & 0.55 & 55.21 & 9.66 & 16.40 \\
\hline$T_{6}$ & $\mathbf{Z n}_{25} \mathbf{F e}_{0}$ & 1.67 & 0.32 & 0.56 & 47.25 & 9.02 & 15.89 \\
\hline $\mathbf{T}_{7}$ & $\mathbf{Z n}_{25} \mathrm{Fe}_{0.5}$ & 1.69 & 0.32 & 0.56 & 49.35 & 9.33 & 16.28 \\
\hline $\mathbf{T}_{8}$ & $\mathrm{Zn}_{25} \mathrm{Fe}_{1.0}$ & 1.65 & 0.30 & 0.58 & 48.69 & 8.90 & 16.98 \\
\hline $\mathbf{T}_{9}$ & $\mathbf{Z n}_{25} \mathrm{Fe}_{1.5}$ & 1.86 & 0.32 & 0.53 & 53.85 & 9.22 & 15.45 \\
\hline $\mathbf{T}_{10}$ & $\mathbf{Z n}_{25} \mathrm{Fe}_{50}$ & 1.60 & 0.32 & 0.55 & 49.45 & 9.95 & 17.01 \\
\hline & SEm \pm & 0.09 & 0.01 & 0.02 & 3.27 & 0.50 & 0.60 \\
\hline & $D$ at $5 \%$ & NS & NS & NS & NS & NS & NS \\
\hline & CV \% & 10.38 & 8.38 & 5.47 & 12.94 & 10.74 & 7.53 \\
\hline
\end{tabular}

Table.2 Effect of treatments on nutrient content and uptake by stover on pearmillet

\begin{tabular}{|c|c|c|c|c|c|c|c|}
\hline \multicolumn{2}{|c|}{ Treatments } & \multicolumn{3}{|c|}{ Nutrient content in stover (\%) } & \multicolumn{3}{|c|}{$\begin{array}{c}\text { Nutrient uptake by stover (kg ha } \\
1 \text { ) }\end{array}$} \\
\hline & & $\mathbf{N}$ & $\mathbf{P}$ & $\mathbf{K}$ & $\mathbf{N}$ & $\mathbf{P}$ & $\mathbf{K}$ \\
\hline$T_{1}$ & $\mathrm{Zn}_{0} \mathrm{Fe}_{0}$ & 0.68 & 0.09 & 0.92 & 35.22 & 4.66 & 47.95 \\
\hline$T_{2}$ & $\mathrm{Zn}_{0} \mathrm{Fe}_{50}$ & 0.68 & 0.08 & 0.91 & 39.44 & 4.91 & 53.35 \\
\hline $\mathbf{T}_{3}$ & $\mathrm{Zn}_{0.5} \mathrm{Fe}_{50}$ & 0.71 & 0.08 & 0.98 & 42.08 & 4.96 & 58.95 \\
\hline $\mathbf{T}_{4}$ & $\mathrm{Zn}_{1.0} \mathrm{Fe}_{50}$ & 0.71 & 0.09 & 0.90 & 43.13 & 5.46 & 54.67 \\
\hline$T_{5}$ & $\mathbf{Z n}_{1.5} \mathbf{F e}_{50}$ & 0.67 & 0.08 & 0.93 & 41.40 & 5.21 & 58.13 \\
\hline$T_{6}$ & $\mathbf{Z n}_{25} \mathrm{Fe}_{0}$ & 0.72 & 0.10 & 0.95 & 42.63 & 5.64 & 56.51 \\
\hline $\mathbf{T}_{7}$ & $\mathbf{Z n}_{25} \mathrm{Fe}_{0.5}$ & 0.69 & 0.10 & 0.90 & 41.20 & 5.78 & 53.74 \\
\hline$T_{8}$ & $\mathrm{Zn}_{25} \mathrm{Fe}_{1.0}$ & 0.67 & 0.09 & 1.08 & 40.11 & 5.39 & 64.54 \\
\hline $\mathbf{T}_{9}$ & $\mathrm{Zn}_{25} \mathrm{Fe}_{1.5}$ & 0.74 & 0.09 & 1.06 & 44.70 & 5.73 & 64.01 \\
\hline$T_{10}$ & $\mathbf{Z n}_{25} \mathrm{Fe}_{50}$ & 0.70 & 0.09 & 0.97 & 43.55 & 5.78 & 60.17 \\
\hline & SEm \pm & 0.04 & 0.01 & 0.07 & 2.16 & 0.46 & 4.49 \\
\hline & at $\overline{5 \%}$ & NS & NS & NS & NS & NS & NS \\
\hline & CV \% & 10.15 & 14.41 & 14.32 & 10.46 & 17.20 & 15.70 \\
\hline
\end{tabular}


Nitrogen, phosphorus and potash uptake by grain influenced by zinc and iron application are given in Table 1.A perusal of data (Table 1) revealed that application of zinc and iron failed to show any significant effect on $\mathrm{N}, \mathrm{P}$ and $\mathrm{K}$ uptake by grain. However, higher nitrogen uptake by grain $\left(55.21 \mathrm{~kg} \mathrm{ha}^{-1}\right)$ was found under application of $1.5 \mathrm{~kg}$ chelated $\mathrm{Zn}$ $\mathrm{ha}^{-1}+50 \mathrm{~kg} \mathrm{FeSO}_{4} \mathrm{ha}^{-1}\left(\mathrm{~T}_{5}\right)$. Though results are non-significant, increasing trend in uptake of phosphorus and potash were recorded. Application of $25 \mathrm{~kg} \mathrm{ZnSO}_{4} \mathrm{ha}^{-1}$ and $50 \mathrm{~kg}$ $\mathrm{FeSO}_{4} \mathrm{ha}^{-1}\left(\mathrm{~T}_{10}\right)$ gave higher uptake of $\mathrm{P}(9.95$ $\left.\mathrm{kg} \mathrm{ha}^{-1}\right)$ and $\mathrm{K}\left(17.01 \mathrm{~kg} \mathrm{ha}^{-1}\right)$ as compare to control. The beneficial role of zinc in increasing cation exchange capacity of roots helped in increasing absorption of nutrients from the soil might have also increased zinc uptake. These results are in close conformity with Das et al., (2004) and Patel et al., (2008). The increasing trend in uptake of N, P and $\mathrm{K}$ was similar to that of in grain and stover yield of pearl millet.

\section{Effect of treatment on nutrient content and uptake by stover on pear millet}

Nitrogen, phosphorus and potash content of pearl millet stover as influenced by of zinc and iron application are furnished in Table 2. The experimental data indicated similar results as $\mathrm{N}, \mathrm{P}$ and $\mathrm{K}$ content in grain. The application of zinc and iron treatments failed to show the significant improvement on $\mathrm{N}, \mathrm{P}$ and $\mathrm{K}$ content of straw. However, numerically higher value for $\mathrm{N}(0.74 \%)$ under application of $25 \mathrm{~kg} \mathrm{ZnSO}_{4} \mathrm{ha}^{-1}+1.5 \mathrm{~kg} \mathrm{Fe} \mathrm{ha}^{-1}\left(\mathrm{~T}_{9}\right)$ and for $\mathrm{K}(1.08 \%)$ with application of $25 \mathrm{~kg}$ $\mathrm{ZnSO}_{4} \mathrm{ha}^{-1}+1.0 \mathrm{~kg} \mathrm{Fe} \mathrm{ha}{ }^{-1}\left(\mathrm{~T}_{8}\right)$ were observed.Yadav et al., (1989) reported that increasing $\mathrm{Zn}$ rates from 0,5 and $10 \mathrm{~kg} \mathrm{Zn} \mathrm{ha}$ ${ }^{1}$ did not affect on $\mathrm{N}$ content of stover of pearl millet.

Results in respect of nitrogen, phosphorus and potash uptake by stover $\left(\mathrm{kgha}^{-1}\right)$ at harvest as influenced by zinc and iron treatments are presented in Table 2. None of the treatments of $\mathrm{Zn}$ and $\mathrm{Fe}$ had significant effect on $\mathrm{N}, \mathrm{P}$ and $\mathrm{K}$ uptake by stover. However, improvement in uptake was observed due to application of $\mathrm{Zn}$ and $\mathrm{Fe}$ treatments may be due to increased pearlmillet yield. It was observed in the range of 35.22 to 44.70 for $\mathrm{N}$, 4.66 to 5.78 for $\mathrm{P}$ and 47.95 to $64.54 \mathrm{~kg} \mathrm{ha}^{-1}$ for K. Higher uptake of N, P and Kby straw was reported with soil application of $25 \mathrm{~kg}$ $\mathrm{ZnSO}_{4} \mathrm{ha}^{-1}$ and $50 \mathrm{~kg} \mathrm{FeSO} \mathrm{ha}^{-1}$ (Jain et al., 2018). The non-significant effect of $\mathrm{Zn}$ and $\mathrm{Fe}$ containing fertilizer application was noticed on $\mathrm{N}, \mathrm{P}$ and $\mathrm{K}$ content in grain and stover of pearlmillet. Similarly the N, P and K uptake by pearlmillet were also not affected significantly due to different treatments.

\section{References}

Anonymous (2016-2017). Annual Progress Report, Micronutrient Research Project (ICAR), AAU, Anand.

Bhuriya, K. P., Kharadi, R. R., Dodiya, V. C. and Kumbhar, M. B. (2019). Effect of integrated nutrient management on HCN (Hydrocyanic acid) content of forage sorghum (Sorghum bicolor $L$. Moench) during summer season. International Journal of Chemical Studies, 7(6): 2007-2010.

Das, D. K. \& Karak, T. (2004). Effect of foliar application of different sources of $\mathrm{Zn}$ on the changes in $\mathrm{Zn}$ content, uptake and yield of rice (Oryza sativa L.).Annals of Agricultural Research, 25(2), 253-256.

Jackson, M. L. (1973). Soil Chemical Analysis, Indian edition. Prentice - Hall India Pvt. Ltd., New Delhi.

Jain Amar Kumar., Swarnima Shrivastava \& Vinay Aryas. (2018). Response of organic manures, zinc and iron on soil properties, yield and nutrient uptake by pearl millet crop grown in inceptisols. 
International Journal Pure App. Bioscience. 426-435.

Malik, S. (2015). Pearl millet nutritional values and medicinal uses. International journal of Advances Research and Innovative Ideas in education, 23954396.

Patel, K. P., Patel, A. K., Patel, A. M., Patel, K. C. \& Ramani, V. P. (2008). Effect of multi-micronutrient mixture on yield and uptake of micronutrients by wheat (Triticum aestivum L.) grown on sandy loam soils of North Gujarat. Asian Journal of Soil Science, 3(1), 84-87.

Singh, V. \& Ram, N. (2006). Effect of twenty-four year of cropping and fertilizer use on the availability of micronutrient in a mollisol. Acta Agronomica overiensis, 48 (1), 41-46.

Singh, M. K. \& Prasad, S. K. (2014).Agronomic aspect of zinc biofortification in rice. Proceedings of the National academy of Sciences India section B. Journal of the Indian Society of Soil Science, 51(1), 56-60.

Yadav, J. P., Singh, G. D. \& Keshwa, G. L. (1989). Effect of different forms of nitrogenous fertilizers and levels of zinc on nutrient uptake and yield of pearl millet. Indian Journal of Agronomy, 34(4), 428-430.

\section{How to cite this article:}

Parmar, C. D., R. R. Kharadi and Bhuriya, K. P. 2020. Influence of Various Zinc and Iron Treatments on Nutrient Content and Uptake of Grain and Stover of Pear Millet Crop. Int.J.Curr.Microbiol.App.Sci. 9(08): 3361-3365. doi: https://doi.org/10.20546/ijcmas.2020.908.387 